03-11-2017

\title{
Low-Temperature Methanol Steam Reforming Kinetics over a novel CuZrDyAl
}

\section{Catalyst}

\section{Hugo Silva, Paulo Ribeirinha, Marta Boaventura, Cecilia Mateos-Pedrero*, Adelio} Mendes* $^{*}$

LEPABE-Departamento de Engenharia Química, Faculdade de Engenharia da Universidade do Porto, Rua Dr. Roberto Frias, 4200-465 Porto, Portugal

*Corresponding authors:

\begin{abstract}
A kinetic study within the low-temperature methanol steam reforming (MSR) reaction range $\left(170{ }^{\circ} \mathrm{C}-200{ }^{\circ} \mathrm{C}\right)$ was performed over a novel CuZrDyAl catalyst. The physicochemical and catalytic properties of the CuZrDyAl catalyst were compared with those of a conventional $\mathrm{CuO} / \mathrm{ZnO} / \mathrm{Al}_{2} \mathrm{O}_{3}$ (G66 MR, Süd-Chemie) sample, taken as reference. The in-house catalyst displays better performances, in terms of methanol conversion and $\mathrm{H}_{2}$ production, than the reference G66 MR sample. Interestingly, the in-house catalyst is significantly more selective (namely, yielding lower CO concentration) than the commercial one, which gives extra interest for producing fuel cell grade hydrogen. Physicochemical characterization evidences that the in-house catalyst have improved reducibility of copper species compared with the G66-MR, which might account for its better performances.
\end{abstract}

The parameters of a simple power-law equation and two mechanistic kinetic models were determined by non-linear regression, minimizing the sum of the residual squares; the best fitting with the experimental data was obtained when using Model 3, based on the reported work from Peppley et al. [10] for the commercial $\mathrm{CuO} / \mathrm{ZnO} / \mathrm{Al}_{2} \mathrm{O}_{3}$. 
03-11-2017

Noteworthy, is the scarce number of MSR kinetic studies at such lower temperature range.

\section{Introduction}

Hydrogen is considered the energy vector of the future where fuel cells are expected to have a key role as energy converting devices with high efficiency [1]. Despite being a clean energy carrier, handling and storage an explosive gas such as hydrogen requires special conditions and special materials to minimize diffusion and leakages [2]. Different techniques are currently been considered: the use of hydrogen tanks at very high pressures (up to 700 bar), hydrogen liquefaction and the use of chemical substances that have the capacity of reacting reversely with hydrogen, such as metallic and organic hydrides [3]. Nevertheless, none of the mentioned techniques can reach competitive volumetric energy densities levels of common fuels. For example, liquid hydrogen has a volumetric energy density of $9.8 \mathrm{MJ} \cdot \mathrm{L}^{-1}[4]$, ca.3-4 times lower than gasoline or diesel fuels. This has engaged the search of parallel strategies to provide hydrogen grade for fuel cells, namely the in situ reforming of fuels such as methanol, DME, ethanol or methane. Methanol has, however, unique advantages: it is liquid fuel at ambient conditions with a volumetric energy density of $15.9 \mathrm{MJ} \cdot \mathrm{L}^{-1}$ (LHV) -[4]); it has a high hydrogen to carbon ratio with no carbon-carbon covalent bonds, which opens the possibility of low-temperature reforming $\left(150-300{ }^{\circ} \mathrm{C}\right)[5,6]$. However, this strategy has a key challenge, which is the undesirable production of carbon monoxide (CO) during sideways reactions of methanol steam reforming (MSR), methanol decomposition (MD) and reverse water-gas shift (RWGS):

$$
\mathrm{CH}_{3} \mathrm{OH} \rightleftarrows \mathrm{CO}+2 \mathrm{H}_{2} \quad \Delta H=92.0 \mathrm{kJmol}^{-1}
$$


03-11-2017

$$
\mathrm{CO}_{2}+\mathrm{H}_{2} \rightleftarrows \mathrm{CO}+\mathrm{H}_{2} \mathrm{O} \quad \Delta H=41.2 \mathrm{kJmol}^{-1}
$$

Carbon monoxide has a detrimental influence on the performance of fuel cells consequence of the well-known poisoning effect on the Pt-based electrochemical anode catalyst of the polymer electrolyte membrane fuel cells (PEMFC). Hydrogen grade standards for fuel cell vehicles refer that the $\mathrm{CO}$ concentration should be below $0.2 \mathrm{ppm}$ [7]. Recently high temperature polymer electrolyte membrane fuel cells (HT-PEMFC) technology, which operate in temperature range of $160{ }^{\circ} \mathrm{C}$ and $200{ }^{\circ} \mathrm{C}$, shifted the limit of $\mathrm{CO}$ concentration to ca. $0.1 \%(1000 \mathrm{ppm})$ at $170^{\circ} \mathrm{C}$. As additional advantages HTPEMFCs have higher electrochemical catalytic activity, simpler water management and simpler system architectures of integration with methanol steam reformers compared to low-temperature PEMFC. Preferential oxidation reactors, humidifiers, air compressors and radiators are among the dispensable process units [8].

The integration of a methanol reformer with HT-PEMFCs can assume different configurations. However, coupling the exothermic electrochemical reactor (HTPEMFC) with the endothermic MSR reactor should result in a significant energy integration if both reactors run at a common temperature; saves of more than ca. $11 \%$ of the methanol fuel energy [9]. Since HT-PEMFCs are limited to operate up to $200{ }^{\circ} \mathrm{C}$, the common temperature should be no more than $200{ }^{\circ} \mathrm{C}$. Thus, the efficiency of a combined system of MSR and HT-PEMFC is highly dependent on the MSR catalyst reaction kinetic at low-temperatures $\left(<200{ }^{\circ} \mathrm{C}\right)$, which defines the purity and flow rate of hydrogen produced.

Since the 1960s the developed copper-based catalysts have revolutionized the methanol reformation process [6]. Presently, a completely tuned and commonly used formulation in the industry is the $\mathrm{CuO} / \mathrm{ZnO} / \mathrm{Al}_{2} \mathrm{O}_{3}$ catalyst $[5,10-12]$. Improving this 
03-11-2017

catalyst in terms of selectivity and activity would have direct repercussion on the integration of low temperature methanol steam reforming (LT-MSR) and HT-PEMFC. Most of the kinetic studies in literature concerns with the $\mathrm{CuO} / \mathrm{ZnO} / \mathrm{Al}_{2} \mathrm{O}_{3}$ catalyst at higher temperature, typically above $200{ }^{\circ} \mathrm{C}$. Moreover, there is still some controversy regarding the MSR reaction mechanism, with several kinetic models proposed in the literature; Peppley et al., developed a Langmuir-Hinshelwood model suggesting two active sites and an overall reaction network of MSR, MD and RWGS [12]. This approach has been used by several authors $[5,13]$.

A novel CuZrDyAl MSR catalyst was prepared and characterized concerning the morphology and composition and the reaction rate at $170{ }^{\circ} \mathrm{C}-200{ }^{\circ} \mathrm{C}$; commercial catalyst G66 MR from Süd-Chemie $\left(\mathrm{CuO} / \mathrm{ZnO} / \mathrm{Al}_{2} \mathrm{O}_{3}\right)$ was used as reference for the reaction rate study. Three kinetic models were fitted to the experimental reaction rates, one empirical [14] and two mechanistic [12, 15].

\section{Experimental}

\subsection{Catalyst Synthesis}

A CuZrDyAl sample was prepared by coprecipitation from a $0.8 \mathrm{M}$ aqueous mixture of copper nitrate trihydrate $\left(\mathrm{Cu}\left(\mathrm{NO}_{3}\right)_{2} \cdot 3 \mathrm{H}_{2} \mathrm{O}\right.$, VWR), zirconyl nitrate dihydrate $\left(\mathrm{ZrO}\left(\mathrm{NO}_{3}\right)_{2} \cdot 2 \mathrm{H}_{2} \mathrm{O}\right.$, Wako), aluminum nitrate nonahydrate $\left(\mathrm{Al}\left(\mathrm{NO}_{3}\right)_{3} \cdot 9 \mathrm{H}_{2} \mathrm{O}\right.$, VWR chemicals) and dysprosium nitrate hydrate $\left(\mathrm{Dy}\left(\mathrm{NO}_{3}\right)_{3} \cdot \mathrm{H}_{2} \mathrm{O}\right.$, Sigma-Aldrich), with dropwise $(0.64 \mathrm{ml} / \mathrm{min})$ addition of an aqueous solution of $\mathrm{Na}_{2} \mathrm{CO}_{3}(0.9 \mathrm{M})$ under vigorous stirring at $50{ }^{\circ} \mathrm{C}$. The resulting precipitate was filtered and thoroughly washed with distilled water. The procedure was repeated for several times until the $\mathrm{pH}$ value of the filtrate reached the level of the distilled water. The precipitate was then dried at 110 
03-11-2017

${ }^{\circ} \mathrm{C}$ overnight and calcined under static air as follows: from $25^{\circ} \mathrm{C}$ to $200{ }^{\circ} \mathrm{C}$ (heating rate:

$2{ }^{\circ} \mathrm{C} / \mathrm{min}$; dwell time: $1 \mathrm{~h}$ ), from $200^{\circ} \mathrm{C}$ to $360^{\circ} \mathrm{C}$ (heating rate: $2{ }^{\circ} \mathrm{C} / \mathrm{min}$; dwell time: 1 h), and finally kept at $360^{\circ} \mathrm{C}$ for $8.5 \mathrm{~h}$.

The $\mathrm{CuO} / \mathrm{ZnO} / \mathrm{Al}_{2} \mathrm{O}_{3}$ (G66 MR from Süd-Chemie) sample was used as supplied.

\subsection{Characterization}

The identification of the crystalline phases was performed by X-ray powder diffraction (XRD), using a Bruker AXS D8 Discover equipment, in $\theta-2 \theta$ mode, with a step of $0.04^{\circ}$ and an integration time of $2 \mathrm{~s}$. The mean size of $\mathrm{CuO}$ crystallites was determined based on XRD peak broadening using the Scherrer equation:

$$
D=K \lambda(\beta \cos \theta)
$$

Where $D$ is the average size of the $\mathrm{CuO}$ crystallites (nm), $K$ is the crystalliteshape factor, $\lambda$ is the wavelength of the $\mathrm{K} \alpha$ radiation of $\mathrm{Cu}(\lambda=1.5418 \AA), \theta$ is the Bragg angle, and $\beta$ is the broadening of the diffraction line measured at half maximum intensity (FWHM). The average particle size was estimated by assuming all the particles to have same spherical shape and size, so that $K$ was 0.9

The characterization by Scanning Electron Microscopy (SEM) was performed using a FEI Quanta 400 scanning electron microscope equipped with an energy dispersive X-ray high vacuum detector (EDX). The SEM images were captured at low vacuum using the large field detector (LFD).

Induced coupled plasma (ICP-MS) analyses were carried out in a Thermo X Series equipment and samples digested in a high concentrated nitric acid solution. 
03-11-2017

The reducibility of the CuZrDyAl catalyst was studied by hydrogen temperature programmed reduction $\left(\mathrm{H}_{2}-\mathrm{TPR}\right)$ measurements under a $5 \%$ hydrogen stream diluted in argon at a total flow rate of $50 \mathrm{~cm}^{3} \cdot \mathrm{min}^{-1}$. The TPR profiles were obtained with an automatic chemisorption analyzer (ChemBET Pulsar TPR/TPD). $50 \mathrm{mg}$ of sample was placed in a long $\mathrm{U}$-shaped quartz cell and heated from $50{ }^{\circ} \mathrm{C}$ to $400{ }^{\circ} \mathrm{C}$ at a rate of $5{ }^{\circ} \mathrm{C} \cdot \min ^{-1}$. Hydrogen consumption was measured by a thermal conductivity detector (TCD). A copper oxide sample (CuO, Riedel-de Haën) was used as reference material.

\subsection{MSR: Fixed-bed Tests}

The MSR reaction rates were obtained at atmospheric pressure in an in-house built set-up [5]. The experimental set-up uses a tubular reactor $(7.25 \mathrm{~mm}$ i.d., $6 \mathrm{~cm}$ length) placed inside an oven. Plug flow conditions were assumed since catalyst diameter to reactor length ratio was higher than $50\left(L_{\text {reactor }} / d_{\text {particle }} \geq 50\right)$ and the reactor to catalyst diameter ratio was higher than $30\left(d_{\text {reactor }} / d_{\text {particle }} \geq 30\right)[16]$.

The reaction was performed with a mass of $400 \mathrm{mg}$ of catalyst $(W)$ and the methanol flow rate $\left(F^{0}\right)$ was changed to obtain different space-time ratios $\left(W / F^{0}\right)$. The water:methanol molar ratio was 1.5 . Kinetic experiments were performed in the temperature range of $170{ }^{\circ} \mathrm{C}$ to $200^{\circ} \mathrm{C}$. Catalyst was reduced in situ using a $40 \%$ hydrogen in argon stream at $240{ }^{\circ} \mathrm{C}$ for $2 \mathrm{~h}$. The gas feed flow rate was controlled by mass flow controllers from Bronkhorst (model F-201C, $\pm 0.1 \mathrm{FS}$ ). Required flow rate of methanol aqueous solution was controlled using a Controlled Evaporation and Mixing (CEM) system from Bronkhorst. The condensable reactants were separated from the gas mixture in a condenser at ca. $0{ }^{\circ} \mathrm{C}$. Hydrogen and carbon dioxide were analyzed in a 
03-11-2017

quadruple mass spectrometer (Pfeiffer, Vacuum OmniStar GSD 320). Carbon monoxide concentration was measured using CO infrared analyzer from Signal Instruments (7100 FM) with accuracy of $\pm 0.2 \mathrm{ppm}$. The methanol steam reforming conversion $\left(X_{\mathrm{CH}_{3} \mathrm{OH}}\right)$ was determined using equations (1) and (2), respectively:

$X_{\mathrm{CH}_{3} \mathrm{OH}}(\%)=\frac{F_{\mathrm{Co}_{2}}^{\text {out }}+F_{\mathrm{CO}}^{\text {out }}}{F_{\mathrm{CH}_{3} \mathrm{OH}}^{\text {On }}} \times 100$

where $F_{\mathrm{CO}_{2}}^{\text {out }}$ and $F_{\mathrm{CO}}^{\text {out }}$ are carbon dioxide and carbon monoxide outlet molar flow rates and $F_{\mathrm{CH}_{3} \mathrm{OH}}^{\text {in }}$ is the inlet methanol molar flow rate.

\section{Results and Discussion}

\subsection{Physicochemical characterization}

The physicochemical properties of the in-house CuZrDyAl and the as-received $\mathrm{CuO} / \mathrm{ZnO} / \mathrm{Al}_{2} \mathrm{O}_{3}$ catalysts (hereafter denoted as $\mathrm{G} 66 \mathrm{MR}$ ) were evaluated by means of the following techniques: ICP-MS (catalyst composition), $\mathrm{N}_{2}$-physisorption (BET surface area), SEM-EDX (structure), XRD (crystallinity) and $\mathrm{H}_{2}$-TPR (reducibility). 
03-11-2017

The composition of both samples determined by ICP is given in Table 1. A weight percentage of $\mathrm{CuO} / \mathrm{ZrO}_{2} / \mathrm{Dy}_{2} \mathrm{O}_{3} / \mathrm{Al}_{2} \mathrm{O}_{3}: 65.1 / 19.7 / 4.8 / 10.4$ was found for the CuZrDyAl catalyst, in good agreement with the experimental composition (65/20/5/10).

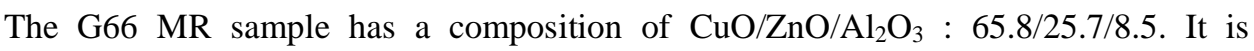
important to note that both samples exhibit nearly the same copper content (ca. 65 wt. \% $\mathrm{CuO}$ ) and, considering that $\mathrm{Cu}$-species are the active sites for MSR reaction, the catalytic differences observed here can be related to a different physicochemical properties.

Figure 1 shows the nitrogen adsorption-desorption isotherm for CuZrDyAl (Fig.1-A) and G66 MR (Fig. 1-B) catalysts. According to the IUPAC classification, the isotherms obtained for both samples appear to be type-IV with a type-H3 hysteresis loop, indicating a mesoporous structure. Although both samples showed the same type of isotherm, clearly the amount of adsorbed nitrogen was different (Figs. 1A-B). Accordingly, the specific surface area and pore volume values of CuZrDyAl $\left(98 \mathrm{~m}^{2} / \mathrm{g}\right.$; Vp: $\left.0.61 \mathrm{~cm}^{3} / \mathrm{g}\right)$ are significantly higher than those of G66 MR $\left(60 \mathrm{~m}^{2} / \mathrm{g} ; \mathrm{Vp}\right.$ : $\left.0.36 \mathrm{~cm}^{3} / \mathrm{g}\right)$. 
03-11-2017
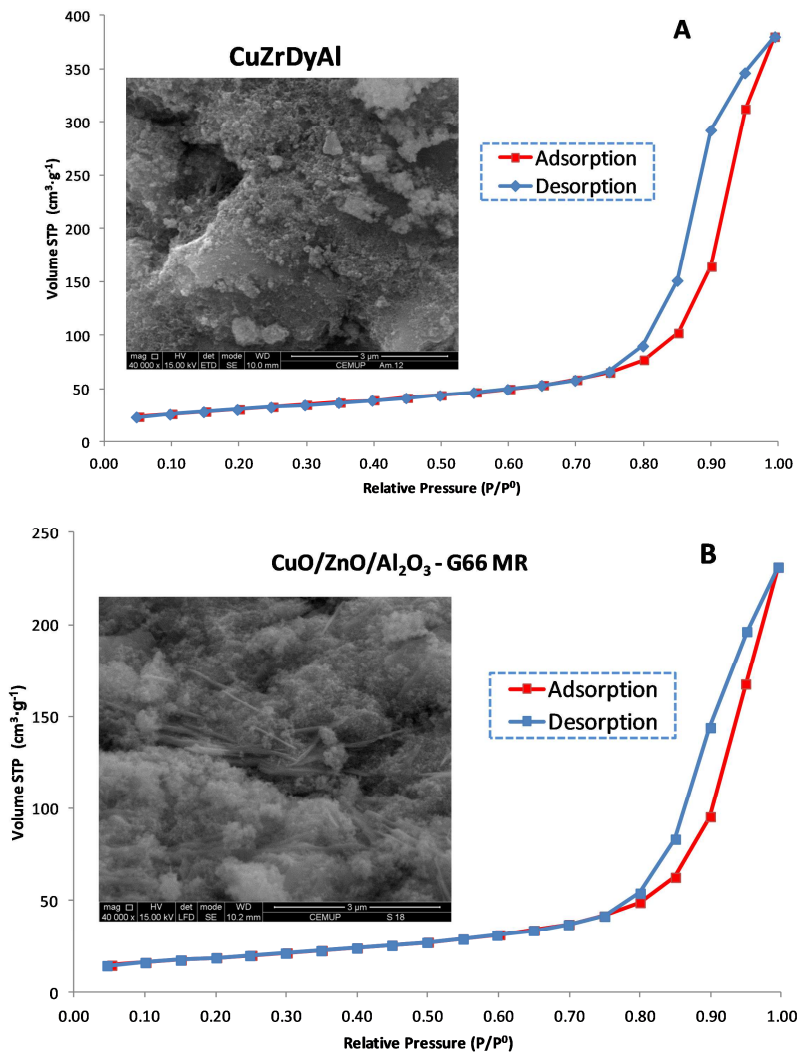

Figure 1 - Nitrogen adsorption-desorption isotherm measured on CuZrDyAl (A) and G66 MR (B) samples. Inset are SEM images of both samples with a magnification of $40000 \mathrm{X}$.

The pore size distribution for both samples determined by the Barret-JoynerHalenda $(\mathrm{BJH})$ method are shown in Figure 2. Both samples exhibit a unimodal pore size distribution with most of the pores having sizes of $17.4 \mathrm{~nm}$. 
03-11-2017
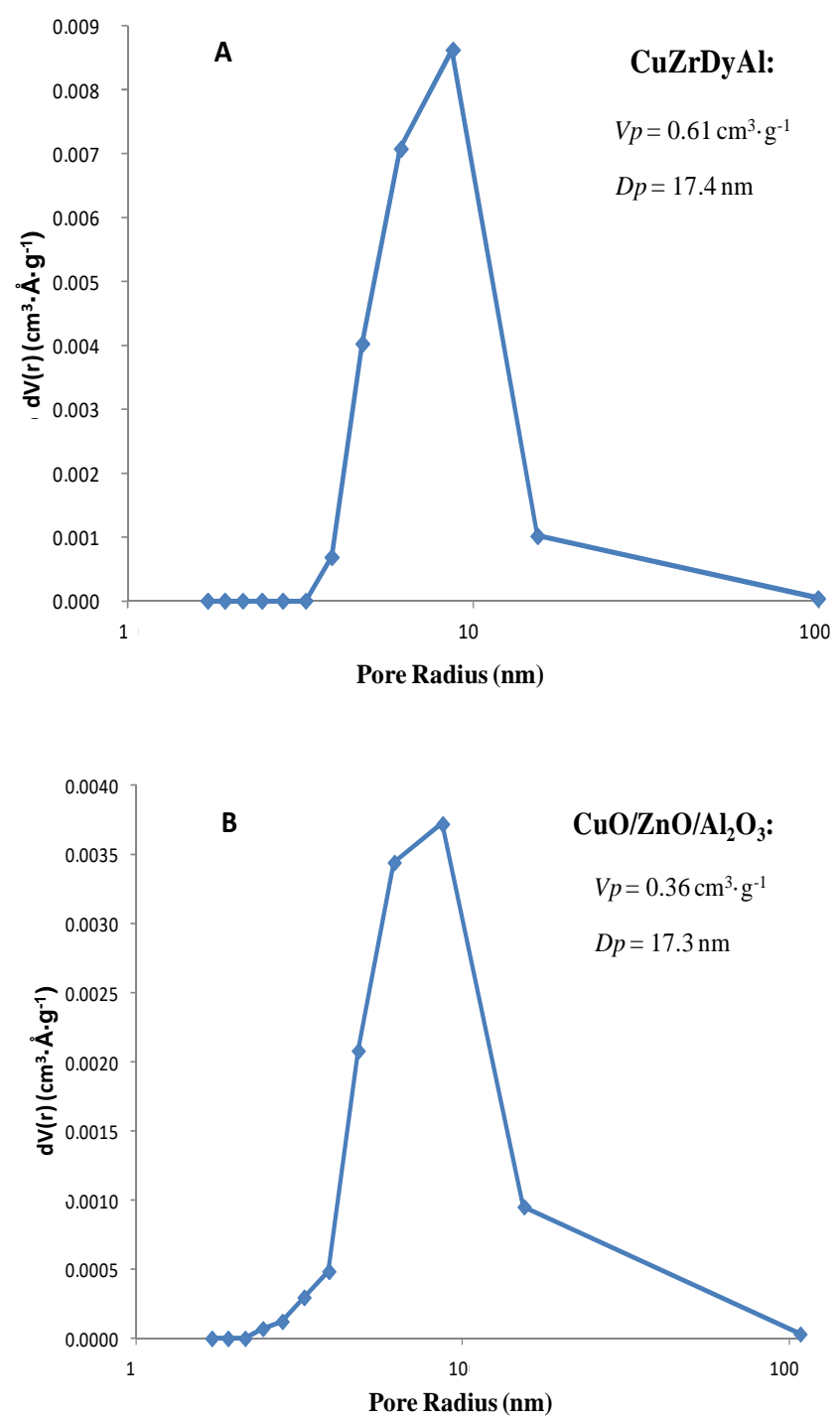

Figure 2: Pore size distribution calculated using the BJH method from the desorption curve of the isotherm; $V p$ and $D p$ stands for pore volume and pore diameter, respectively.

The XRD patterns of both samples are displayed in Fig. 3. All the diffraction lines of the $\mathrm{CuZrDyAl}$ sample can be indexed using the tenorite phase of $\mathrm{CuO}$ (ICDD file number 00-048-1548). As apparent in Fig. 3, no diffraction lines of any Al, $\mathrm{Zr}$ or Dy compounds were observed for $\mathrm{CuZrDyAl}$, suggesting that these species were highly 
03-11-2017

dispersed in this sample. In the case of the G66 MR sample, besides tenorite phase, additional features ascribed to zinc oxide ( $\mathrm{ZnO}$ - ICDD file number 01-089-1397) and aluminum oxide $\left(\mathrm{Al}_{2} \mathrm{O}_{3}\right.$ - ICDD file number 01-070-3321) are found (Fig. 3).

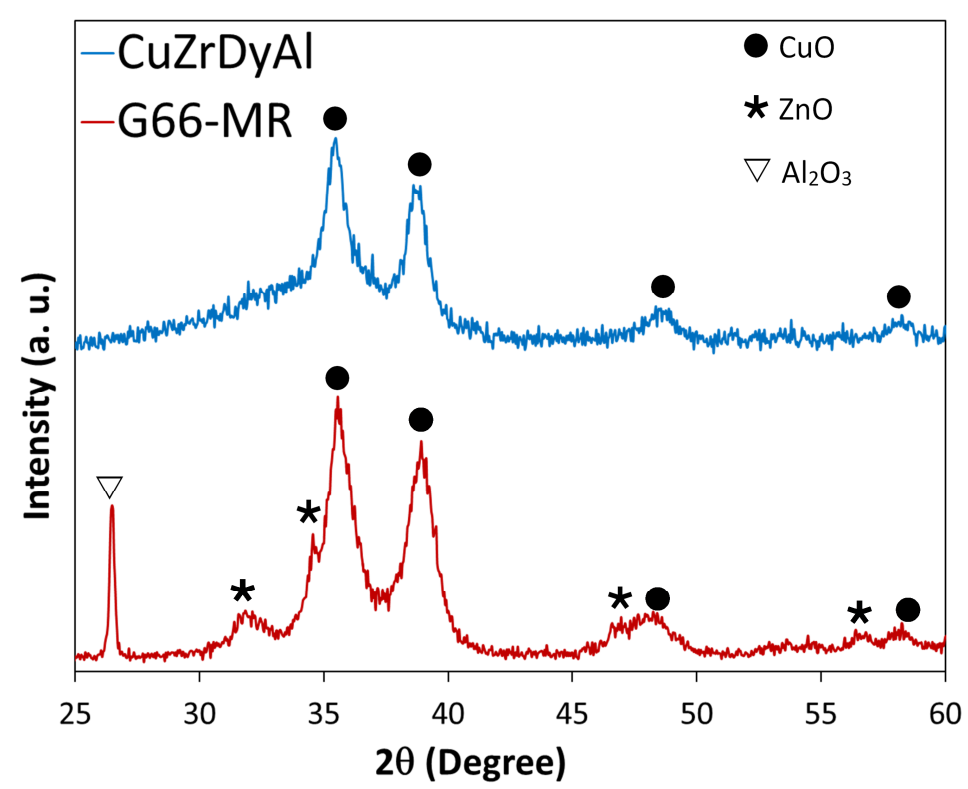

Figure 3: X-Ray diffraction pattern for CuZrDyAl and G66 MR samples.

Both catalysts show broad $\mathrm{CuO}$ peaks, indicating that they are made up of relatively small $\mathrm{CuO}$ particles (note that both catalysts contain 65 wt. \% of $\mathrm{CuO}$ ). The estimated mean crystallite size of $\mathrm{CuO}$ for both samples is in the order of $9 \mathrm{~nm}$ (Table 1). 
03-11-2017

Table 1: Average crystallite size of $\mathrm{CuO}$ determined from the XRD data using the Scherrer equation and chemical composition (ICP) of CuZrDyAl and G66 MR samples.

\begin{tabular}{|l|c|c|}
\hline Sample & $\begin{array}{c}\mathrm{CuO} \text { mean crystallite size } \\
(\mathrm{nm})\end{array}$ & $\begin{array}{c}\text { Chemical composition (ICP) } \\
\text { (wt.\% of metal oxides) }\end{array}$ \\
\hline & & $\mathrm{CuO}=65.1$ \\
$\mathrm{CuZrDyAl}$ & 8.7 & $\mathrm{ZrO}_{2}=19.7$ \\
& & $\mathrm{Dy}_{2} \mathrm{O}_{3}=4.8$ \\
$\mathrm{Al}_{2} \mathrm{O}_{3}=10.4$
\end{tabular}

The $\mathrm{H}_{2}$-TPR profiles of CuZrDyAl and G66 MR catalysts are presented in Fig. 4. The TPR curve of a bare $\mathrm{CuO}$ sample is also included in this figure for comparative purposes. Clearly, and not surprisingly, CuZrDyAl and G66 MR catalysts are reduced at much lower temperatures than the reference $\mathrm{CuO}$ sample (Fig. 4, Table 2). This is in line with reported data, since addition of promoters, such as $\mathrm{ZrO}_{2}$ and $\mathrm{ZnO}$, results in catalysts that are easier to reduce than their unpromoted counterparts [17-19].

The TPR profile of pure $\mathrm{CuO}$ (Fig. 4, Table 2) is characterized by two reduction peaks at ca. $280{ }^{\circ} \mathrm{C}(\mathrm{P} 1)$ and $320^{\circ} \mathrm{C}(\mathrm{P} 2)$. According to other published works [19-21] and reference 18 of the present study), the presence of two reduction signals in bulk $\mathrm{CuO}$ is attributed to the stepwise reduction of copper oxide according to the following equation:

$$
\mathrm{Cu}^{2+} \rightarrow \mathrm{Cu}^{+} \rightarrow \mathrm{Cu}^{0}
$$

Thus, one can assume that $\mathrm{P} 1$ and $\mathrm{P} 2$ peaks in Fig. 4 correspond to the two-step reduction from $\mathrm{Cu}^{2+}$ to $\mathrm{Cu}^{0}$ described by Eq. 5 . 


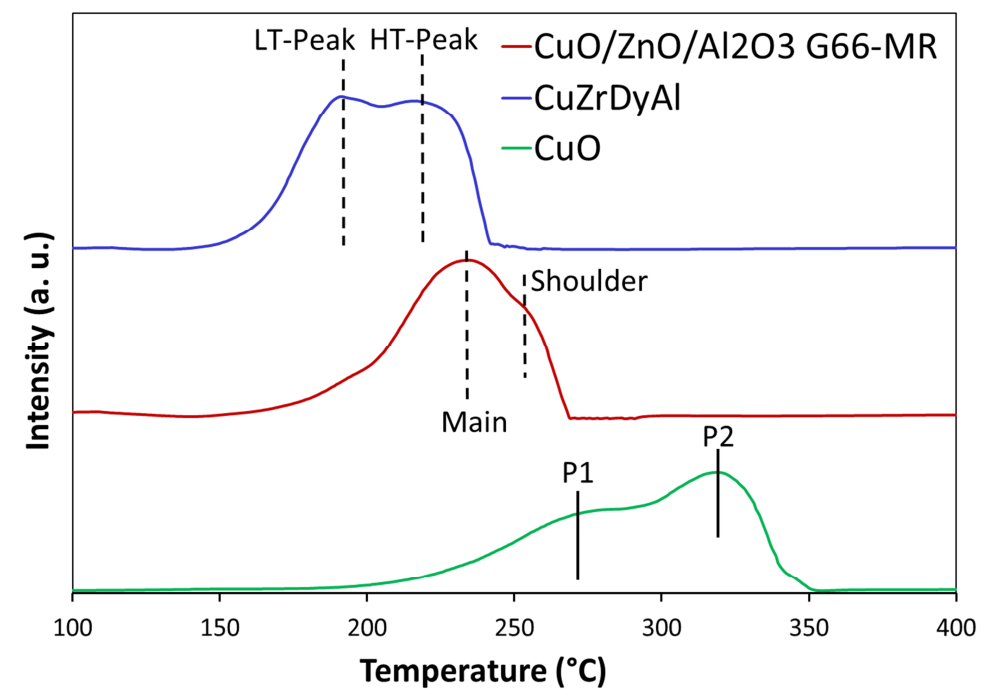

Figure 4. $\mathrm{H}_{2}$-TPR profiles of the CuZrDyAl and G66-MR catalysts. The $\mathrm{H}_{2}$-TPR profile of a bulk $\mathrm{CuO}$ is also shown for comparison.

It is interesting to note that the reduction temperature of copper in the CuZrDyAl sample is significantly lower (by about $45^{\circ} \mathrm{C}$; Table 2) than that of the G66-MR sample (Fig. 4, Table 2), although both samples have similar copper content (Table 1). On the other hand, the shape of the TPR curve of both catalysts is clearly different (Fig. 4). The TPR profile of the in-house catalyst displays two distinct reduction peaks, a major peak at a lower temperature (LT-peak in Fig. 4), which represents about $75 \%$ of the overall peak area, and the other peak at higher temperature (HT-peak in Fig. 4).

The occurrence of two peaks in the CuZrDyAl sample could be due to the presence of: (i) copper oxide species with different particle sizes; and/or (ii) copper species differently interacting with the zirconia-rich matrix. The present findings also confirmed previous results reporting on the existence of two reduction peaks for binary $\mathrm{Cu} / \mathrm{ZrO}_{2}$ samples $[22,23][$ Ref. $\mathrm{F}$ and Ref. 21 of the present study]. The authors attributed this behavior to the presence of different copper- $\mathrm{ZrO}_{2}$ interactions. 
03-11-2017

Table 2: $\mathrm{H}_{2}$-TPR data of bare $\mathrm{CuO}, \mathrm{CuZrDyAl}$ and G66 MR catalysts.

\begin{tabular}{ccc}
\hline Sample & $\begin{array}{c}\text { LT-peak } \\
\left({ }^{\mathbf{O}} \mathbf{C}\right)\end{array}$ & $\begin{array}{c}\text { HT-peak } \\
\left({ }^{\circ} \mathbf{C}\right)\end{array}$ \\
\hline Pure CuO & 280 & 320 \\
G66 MR & 235 & 255 \\
CuZrDyAl & 191 & 221 \\
\hline
\end{tabular}

As seen in Fig. 4, the G66-MR sample was fully reduced between 165 and 270 ${ }^{\circ} \mathrm{C}$. Unlike the in-house sample, the G66-MR shows a single broad peak centered at 235 ${ }^{\circ} \mathrm{C}$ with a small shoulder around $255^{\circ} \mathrm{C}$.

The present findings unequivocally evidence that the reducibility of $\mathrm{CuO}$ was significantly improved in the CuZrDyAl catalyst. The addition of $\mathrm{Zr}$ and $\mathrm{Dy}$ as promoters allows to lower the $\mathrm{CuO}$ reduction temperature, which is likely due to the strong interaction of copper species with the ZrDy-containing matrix. Two kinds of copper species are present on the surface of the in-house catalyst which are responsible for the two reduction peaks observed during the reduction of this sample.

To sum up, the in-house CuZrDyAl and G66 MR catalysts were characterized according to their, elemental composition, textural properties, crystallinity and reducibility. According to $\mathrm{XRD}$ both samples have similar $\mathrm{CuO}$ particle size although the in-house sample has a higher specific surface area. The main difference between both samples is undoubtedly the reducibility of $\mathrm{CuO}$ that is noticeably enhanced in the CuZrDyAl catalyst. 
03-11-2017

\subsection{Kinetic Models}

In the literature, can be found several different kinetic models for MSR reaction; some are simple and empirical, while others are based on mechanistic assumptions. Presently, four different reaction processes are considered in methanol reforming, such as: methanol decomposition, partial oxidation of methanol, steam reforming of methanol and oxidative steam reforming of methanol [24]. The sequence of the reaction is one that brings to $\mathrm{H}_{2}$ formation is subject of different pathway proposals and discussion. Some authors, consider the CO formation from RWGS excluding MD [11, 15] and others include a network of three reactions were MD has also a contribution. For instance, Peppley et al., has reported a kinetic model that includes: MD, RWGS and MSR [12].

Since the kinetic experiments in this work were performed at low-temperature $\left(170{ }^{\circ} \mathrm{C}-200^{\circ} \mathrm{C}\right)$, the contribution of $\mathrm{MD}$ as a sideway reaction should be negligible. There are many studies that support this assumption, and attribute the formation of $\mathrm{CO}$ to the RWGS due to the high concentrations of $\mathrm{CO}_{2}$ and $\mathrm{H}_{2}$ in the reaction medium [5, $11,15,25]$.

\subsection{Empirical model}

The use of empirical equations for compute the MSR rate is a common strategy reported in the literature $[5,10,14,26]$. Despite their simplicity, in some cases the experimental results are better fitted using power-laws [27]. Moreover, some authors denote preference for the power-law kinetics when the purpose of the study is to predict the hydrogen and CO production for fuel cells applications [14]. In this work, the 
03-11-2017

following power-law expression was used to describe the experimental results and was designated as Model 1:

$$
-r_{\mathrm{MSR}}=k_{\mathrm{MSR}} P_{\mathrm{CH}_{3} \mathrm{OH}}^{a} P_{\mathrm{H}_{2} \mathrm{O}}^{b} P_{\mathrm{H}_{2}}^{c} P_{\mathrm{CO}_{2}}^{d}
$$

where $k_{\mathrm{MSR}}$ is the kinetic constant of the MSR reaction $\left(k_{\mathrm{MSR}}=k_{0} e^{-E_{a} / R T}\right)$, where $E_{a}$ is the activation energy, $k_{0}$ is the pre-exponential factor, $R$ is the gas constant and $T$ is the absolute temperature - Arrhenius equation); $a, b, c$ and $d$ are the apparent reaction orders of methanol, water, hydrogen and carbon dioxide, respectively. This model has been used in the literature for the MSR reaction on commercial catalyst $\mathrm{CuO} / \mathrm{ZnO} / \mathrm{Al}_{2} \mathrm{O}_{3}[5,14]$. It has a total of 6 parameters, including the activation energy and pre-exponential factor.

\subsection{Mechanistic Models}

There are several mechanistic expressions that describe the kinetics of MSR and there is still controversy regarding this matter in the literature. The first reaction mechanism proposed as sequence the formation of $\mathrm{H}_{2}$ and $\mathrm{CO}$ primarily from MD, and then the water-gas shift (WGS) would occur to produce $\mathrm{CO}_{2}$ and $\mathrm{H}_{2}$ [28]. Other authors stated later that the correct pathway involves the formation of $\mathrm{CO}_{2}$ and $\mathrm{H}_{2}$ through direct MSR, followed by the RWGS reaction [29]. According to the first mechanism, the amount of $\mathrm{CO}$ should be equal or higher to the equilibrium of the RWGS reaction and this condition must be verified for the whole temperature range [11, 15]. However, experimental results have indicated the opposite, meaning that the $\mathrm{CO}$ amount in the temperature range of $160^{\circ} \mathrm{C}$ to $260^{\circ} \mathrm{C}$ was always below the equilibrium of RWGS [5, $11]$. 
The Langmuir-Hinshelwood kinetic equation proposed by Tesser et al. [15] assumes as reaction pathways the direct MSR followed by RWGS that leads to the CO formation. The detrimental effect of the partial pressure of both $\mathrm{H}_{2}$ and $\mathrm{H}_{2} \mathrm{O}$ are included factors on the model equation. This inhibitory effect takes into account the competitive adsorption of the reactants, water and methanol, and of the produced hydrogen on the active site. The former model was applied to the obtained experimental data and was designated as Model 2:

$$
-r_{\mathrm{MSR}}=\frac{k_{\mathrm{MSR}} K_{\mathrm{CH}_{3} \mathrm{OH}} p_{\mathrm{CH}_{3} \mathrm{OH}}}{1+K_{\mathrm{CH}_{3} \mathrm{OH}} p_{\mathrm{CH}_{3} \mathrm{OH}}+K_{\mathrm{H}_{2} \mathrm{O}} p_{\mathrm{H}_{2} \mathrm{O}}+K_{\mathrm{H}_{2}} p_{\mathrm{H}_{2}}}
$$

where $k_{\mathrm{MSR}}$ is the methanol steam reforming kinetic constant; $K_{\mathrm{CH}_{3} \mathrm{OH}}, K_{\mathrm{H}_{2} \mathrm{O}}$ and $K_{\mathrm{H}_{2}}$ are the adsorption equilibrium constants of methanol, water and hydrogen, respectively; $p_{\mathrm{CH}_{3} \mathrm{OH}}, p_{\mathrm{H}_{2} \mathrm{O}}$ and $p_{\mathrm{H}_{2}}$ are the partial pressures of methanol, water and hydrogen, respectively. This model has 8 parameters, including the activation energy and preexponential factor.

Peppley et al. [12] proposed a reaction network considering MSR, MD and RWGS reactions and assume two different active sites on the catalyst, one for hydrogen and the other for oxygen containing species. The resulting rate expression can be written as follows and was designated as Model 3:

$-r_{\mathrm{MSR}}=\frac{\frac{k_{\mathrm{MSR}} K_{\mathrm{CH}_{3} \mathrm{O}^{(1)}} p_{\mathrm{CH}_{3} \mathrm{OH}}}{p_{\mathrm{H}_{2}}^{1 / 2}}\left(1-\frac{p_{\mathrm{H}_{2}}^{3} p_{\mathrm{CO}_{2}}}{K_{S R} p_{\mathrm{H}_{2} \mathrm{O}} p_{\mathrm{CH}_{3} \mathrm{OH}}}\right)}{\left(1+\frac{K_{\mathrm{CH}_{3} \mathrm{O}^{(1)}} p_{\mathrm{CH}_{3} \mathrm{OH}}}{p_{\mathrm{H}_{2}}^{1 / 2}}+\frac{K_{\mathrm{OH}^{(1)}} p_{\mathrm{H}_{2} \mathrm{O}}}{p_{\mathrm{H}_{2}}^{1 / 2}}+K_{\mathrm{HCOO}^{(1)}} p_{\mathrm{H}_{2}}^{1 / 2} p_{\mathrm{CO}_{2}}\right)\left(1+\sqrt{K_{\mathrm{H}^{(1))}} p_{\mathrm{H}_{2}}}\right)}$ 
03-11-2017

where $K_{i}$ are the adsorption equilibrium constants for the intermediate species involved and $K_{\mathrm{MSR}}$ is the equilibrium constant for MSR. The model has a total of 10 parameters, including the activation energy and pre-exponential factor.

The parameters estimation was simplified using the data gathered by Skrzypek $e t$ al. regarding the adsorption of various reactants, products and possible intermediates in methanol synthesis for the $\mathrm{CuO} / \mathrm{ZnO} / \mathrm{Al}_{2} \mathrm{O}_{3}$ commercial catalyst [12]. As a result, the number of parameters estimated was reduced to a total of 6. Lee et al. [11]., studied for a $\mathrm{CuO} / \mathrm{ZnO} / \mathrm{MnO} / \mathrm{Al}_{2} \mathrm{O}_{3}$ catalyst a Langmuir-Hinshelwood model, using primarily the heats of adsorption from Peppley et al. work as constants and afterwards as parameters to estimate. Despite increasing the number of parameters, the inclusion of the heats of adsorption as parameters was reported to not cause any serious error in the kinetics [11]. In this work, the model suggested by Peppley et al. will be studied for both approaches: non-linear regression with 6 and 10 parameters.

\subsection{Parameters estimation}

Assuming the fluid presents a plug flow pattern and there are not mass transfer resistances, the mass balance to the reactor is:

$-\mathrm{d} F=F^{0} \mathrm{~d} X_{\mathrm{CH}_{3} \mathrm{OH}}=\left(-r_{\mathrm{CH}_{3} \mathrm{OH}}\right) \mathrm{d} W$

where $F^{0}$ is the flow rate of methanol and $\left(-r_{\mathrm{CH}_{3} \mathrm{OH}}\right)$ is reaction rate of methanol. Rearranging equation (9) one obtains:

$$
\left(-r_{\mathrm{CH}_{3} \mathrm{OH}}\right)=\frac{\mathrm{d} X_{\mathrm{CH}_{3} \mathrm{OH}}}{\mathrm{d}\left(W / F^{0}\right)}
$$


03-11-2017

where $X_{\mathrm{CH}_{3} \mathrm{OH}}$ is the methanol conversion. The experimental reaction rates are determined by adjusting a polynomial equation to the experimental results followed by the determination of the first derivative (Eq. 10) [11, 12]. The kinetic parameters are obtained by minimizing the mean residual sum of the squares (MSRR) of the experimental and predict reaction rates (Eq. 11):

$M S R R=\frac{\sum_{i=1}^{N}\left(r_{e x p, i}-r_{c a l, i}\right)^{2}}{N-N_{p}}$

where, $r_{\text {exp }, i}$ and $r_{\text {cal }, i}$ are respectively the experimental and predicted reaction rates; $N$ and $N_{p}$ are the number of experimental points $\left(N_{p}=24\right)$ and the number of estimated parameters, respectively.

Figure 7, presents the parity plots for each models and is observed a good fitting between experimental and calculated reaction values. The mechanistic models provide a closer description of the experimental reaction rates, moreover Model 3 present the lowest MSRR, $1.4 \times 10^{-7}$. Accordingly, when comparing Model 3 with Model $3^{*}$ (Table 4), a slightly worst fitting was obtained in Model $3^{*}$; still, the difference between the optimized values for the CuZrDyAl and the data tabled for the conventional catalyst did not cause any serious error in the kinetics, similarly to conclusion of Lee et al. when studying a $\mathrm{CuO} / \mathrm{ZnO} / \mathrm{MnO} / \mathrm{Al}_{2} \mathrm{O}_{3}$ formulation [11]. Finally, Model 2 that considers a very different mechanism of reaction than Model 3 had a $M S R R$ of $1.7 \times 10^{-7}$. This model only considers one active site and neglects the contribution of MD, whereas Model 3 from Peppley et al. work, includes MD and considers 2 active sites, one for oxygenated species and other for hydrogen. 
The validation of model 3 is presented in Figure 8, where is established the comparison between the MSR experimental conversions and the model predictions using a one dimension packed bed simulator described elsewhere [5]. As result, the model fits with accuracy the experimental data for the mechanistic model based on Peppley et al. work. However, in the same figure is possible to verify that the power law model also fits well with the experimental data, despite being a quite simplistic approach.

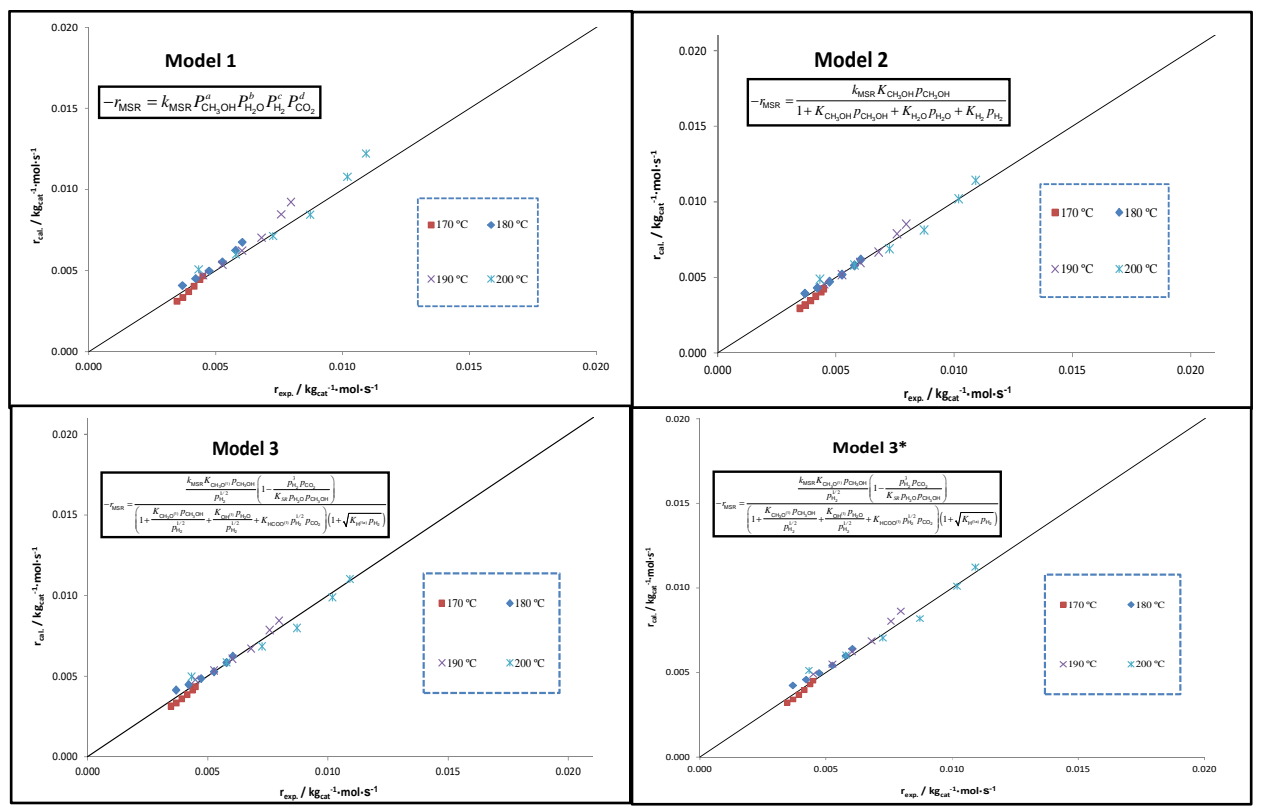

Figure 7 - Parity plots of the experimental and calculated reaction consumption rate using different models.

Table 4 - Parameters determined for the different models. The adsorption equilibrium enthalpies $\left(\Delta H_{i}\right)$ are in $\mathbf{k J} \cdot \mathrm{mol}^{-1}$ and the entropies of adsorption $\left(\Delta S_{i}\right)$ are in and $\mathrm{J} \cdot \mathrm{mol} \cdot \mathrm{k}^{-1}$ values labeled with "p" refers to the data from Peppley $e t$ al. [12].

\section{Temperature}


03-11-2017

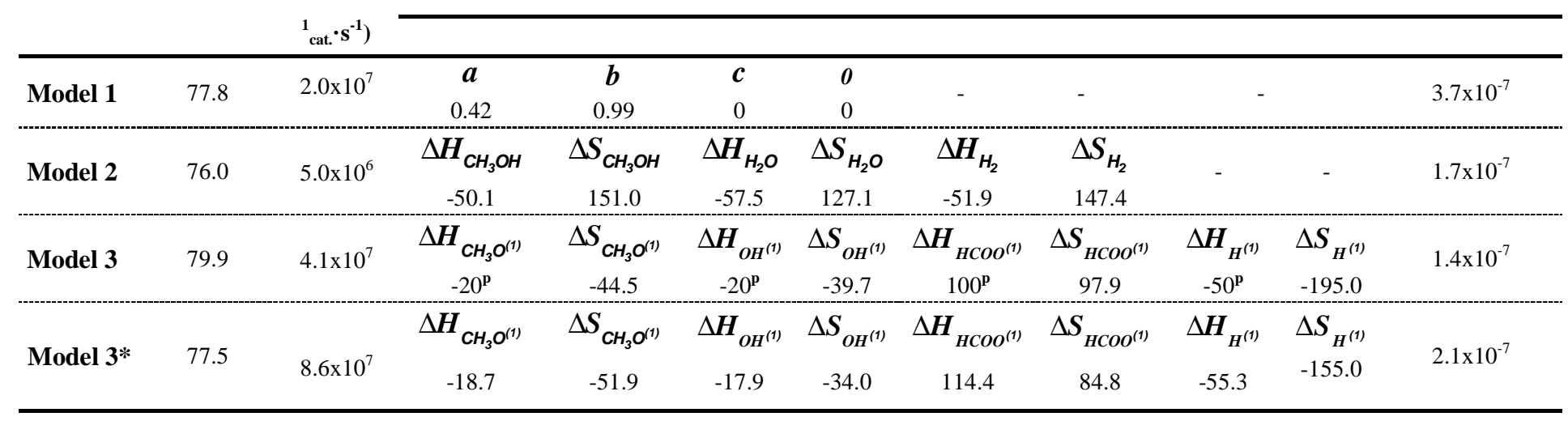
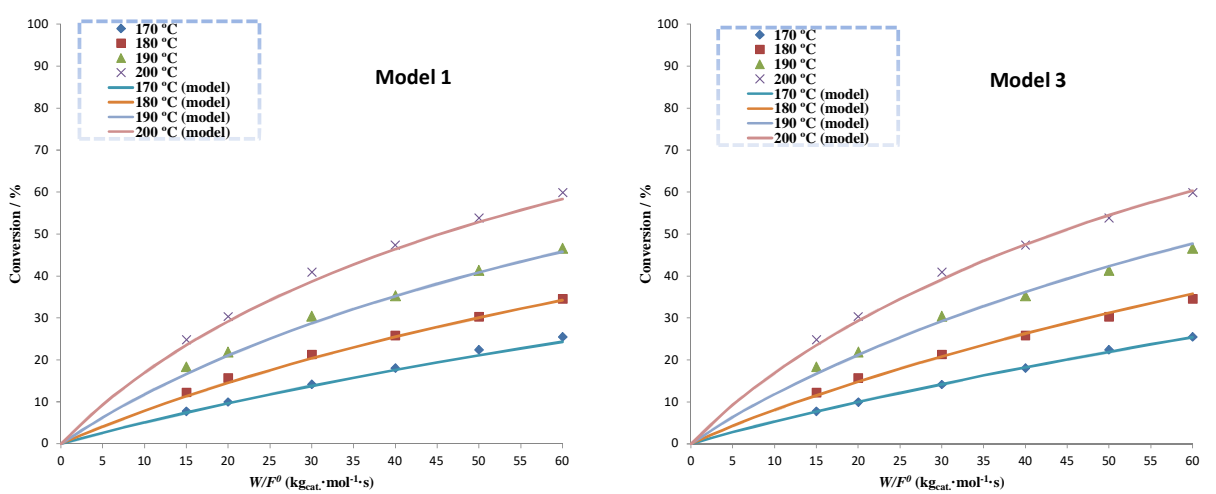

Figure 8 - Experimental and simulated (model 1 and model 3) results for methanol conversion versus the space time ratio at different temperatures;

\subsection{Comparison between the $\mathrm{CuZrDyAl}$ and the $\mathrm{CuO} / \mathrm{ZnO} / \mathrm{Al}_{2} \mathrm{O}_{3}$}

According to the previous section, model 3 is the mechanistic model that exhibits the best fitting. Therefore, a comparison is established between the estimated parameters obtained for $\mathrm{CuZrDyAl}$ and $\mathrm{CuO} / \mathrm{ZnO} / \mathrm{Al}_{2} \mathrm{O}_{3}$ catalysts when using this model - see Table 5. 
03-11-2017

Table 5 - Comparison between the parameters obtained for the $\mathrm{CuO} / \mathrm{ZnO} / \mathrm{Al}_{2} \mathrm{O}_{3}$ and the CuZrDyAl catalysts in this work when considering Model 3.

\begin{tabular}{|c|c|c|}
\hline & $\mathrm{CuO} / \mathrm{ZnO} / \mathrm{Al}_{2} \mathrm{O}_{3}$ & CuZrDyAl \\
\hline$E_{a}\left(\mathrm{~kJ} \cdot \mathrm{mol}^{-1}\right)$ & 86.9 & 79.9 \\
\hline$k_{0}\left(\mathbf{m}^{2} \cdot \mathrm{mol}^{-1} \cdot \mathbf{s}^{-1}\right)$ & $4.0 \times 10^{13}$ & $3.7 \times 10^{12}$ \\
\hline$\Delta S_{\mathrm{CH}_{3} \mathrm{O}^{(I)}}\left(\mathrm{J} \cdot \mathrm{mol} \cdot \mathrm{k}^{-1}\right)$ & -47.9 & -44.5 \\
\hline$\Delta \boldsymbol{H}_{\mathrm{CH}_{3} \mathrm{O}^{(1)}}\left(\mathbf{k J} \cdot \mathbf{m o l}^{-\mathbf{1}}\right)$ & -20 & -20 \\
\hline$\Delta S_{O H^{(1)}}\left(J \cdot m o l \cdot k^{-1}\right)$ & -44.1 & -39.7 \\
\hline$\Delta \boldsymbol{H}_{\mathrm{OH}^{(1)}}\left(\mathrm{kJ} \cdot \mathrm{mol}^{-1}\right)$ & -20 & -20 \\
\hline$\Delta S_{H C O O^{(1)}}\left(\mathrm{J} \cdot \mathrm{mol} \cdot \mathrm{k}^{-1}\right)$ & 100.1 & 97.9 \\
\hline$\Delta H_{H C O O^{(1)}}\left(\mathrm{kJ} \cdot \mathrm{mol}^{-1}\right)$ & 100 & 100 \\
\hline$\Delta S_{H^{(1 a)}}\left(J \cdot m o l \cdot k^{-1}\right)$ & -223.2 & -195.0 \\
\hline$\Delta \boldsymbol{H}_{\boldsymbol{H}^{(1 a)}}\left(\mathrm{kJ} \cdot \mathrm{mol}^{\mathbf{1}}\right)$ & -50 & -50 \\
\hline
\end{tabular}

For the MSR reaction the CuZrDyAl catalyst exhibits activation energy value lower than $\mathrm{CuO} / \mathrm{ZnO} / \mathrm{Al}_{2} \mathrm{O}_{3}$ catalyst (Süd-Chemie, G66 MR), suggesting higher catalytic activity. Therefore, a catalytic test was performed at $180^{\circ} \mathrm{C}$, using the Süd-Chemie G66 MR catalyst. Figure 9, presents the conversion comparison between both catalysts. 
03-11-2017

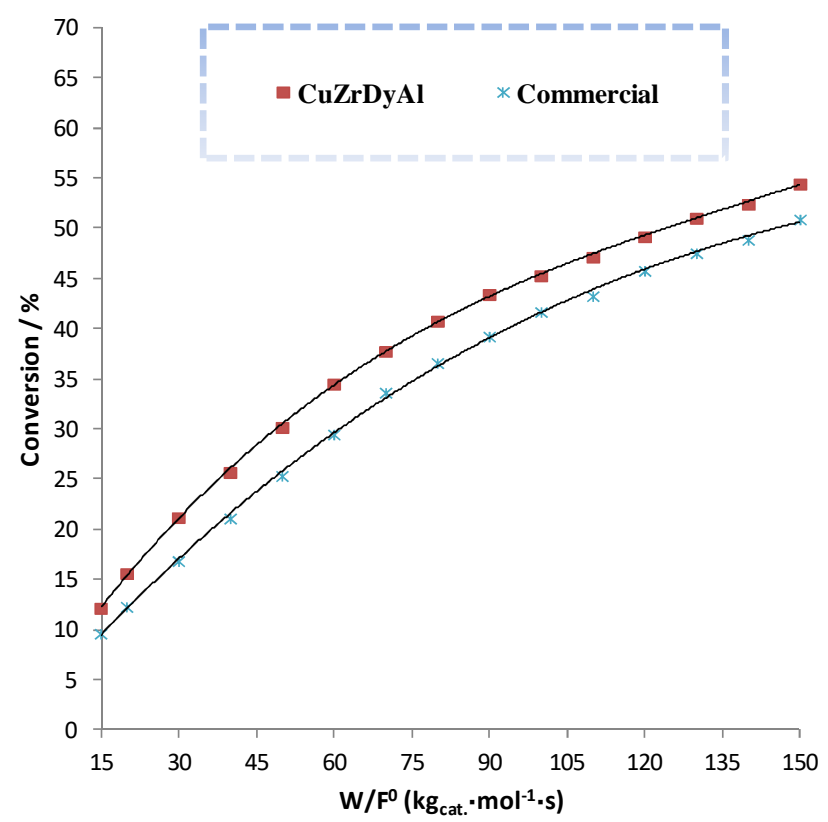

Figure 9 - Comparison of the conversion as function of the space time ratio between the commercial G66-MR (Süd-Chemie) and CuZrDyAl catalysts (lines were added to readability).

In fact, Figure 9 shows that the CuZrDyAl catalyst has a higher activity than the $\mathrm{CuO} / \mathrm{ZnO} / \mathrm{Al}_{2} \mathrm{O}_{3}$ catalyst at $180^{\circ} \mathrm{C}$. Moreover, CuZrDyAl catalyst produces less $\mathrm{CO}$ than commercial catalyst. At space time ratio of $100 \mathrm{~kg}_{\text {cat. }} \cdot \mathrm{mol}^{-1} \cdot \mathrm{s}^{-1}$ and $180^{\circ} \mathrm{C}$ the reformate stream presents $\mathrm{CO}$ content of $60 \mathrm{ppm}$ with $\mathrm{CuZrDyAl}$ catalyst, while with commercial catalyst it presents $90 \mathrm{ppm}$

The developed CuZrDyAl catalyst show to be a very promising formulation for MSR, not only regarding its activity but also the $\mathrm{CO}$ amounts produced. 
03-11-2017

\section{Conclusions}

A novel CuZrDyAl catalyst was synthesized, characterized and tested for lowtemperature MSR $\left(170-200{ }^{\circ} \mathrm{C}\right)$ at a space time ratio between $15 \mathrm{~kg}_{\mathrm{cat}} \cdot \mathrm{mol}^{-1} \cdot \mathrm{s}^{-1}$ and $150 \mathrm{~kg}_{\mathrm{cat}} \cdot \mathrm{mol}^{-1} \cdot \mathrm{s}^{-1}$. The physicochemical study conducted over the in-house CuZrDyAl and the reference G66-MR catalysts indicate that the main difference between them is the improved reducibility of copper oxide on the former sample, which could be attributed to higher dispersion of copper particles and/or the presence of copper species strongly interacting with the $\mathrm{Zr}$-rich matrix.

Three kinetic models were applied to describe the CuZrDyAl experimental reaction rates. Model 3, had a better fitting, which was obtained using JMP software and by a non-linear regression minimizing the sum of the residual squares. The novel formulation was compared with the commercial formulation at $180{ }^{\circ} \mathrm{C}$ and both selectivity and activity were higher for the CuZrDyAl sample. The better performances shown by the in-house sample could be attributed to its enhanced reducibility. This is easily understood, assuming that both catalysts were tested under the same working conditions, so considering that metallic copper particles are the active sites for MSR reaction it is clear that; the higher the reducibility, the higher the activity.

\section{Acknowledgments}


03-11-2017

The research leading to these results has received funding from the European Union's Seventh Framework Programme (FP/2007-2013) for the Fuel Cells and Hydrogen Joint Technology Initiative under grant agreement $n^{\circ}[\underline{303476}$ ]. Hugo Silva wishes to thank FCT-Foundation for Science and technology for the PhD fellowship, SFRH/BD/45890/2008. The authors also acknowledge the financial support from FCT through the project PTDC/EQU-EQU/104217/2008. 
03-11-2017

\section{References}

1. Conte, M., ENERGY / Hydrogen Economy, in Encyclopedia of Electrochemical Power Sources, J. Garche, Editor. 2009, Elsevier: Amsterdam. p. 232-254.

2. Olah, G.A., A. Goeppert, and G.K.S. Prakash, The Hydrogen Economy and its Limitations, in Beyond Oil and Gas: The Methanol Economy. 2009, Wiley-VCH Verlag GmbH \& Co. KGaA. p. 143-178.

3. Yang, J., et al., High capacity hydrogen storage materials: attributes for automotive applications and techniques for materials discovery. Chemical Society Reviews, 2010. 39(2): p. 656-675.

4. Durbin, D.J. and C. Malardier-Jugroot, Review of hydrogen storage techniques for on board vehicle applications. International Journal of Hydrogen Energy, 2013. 38(34): p. 14595-14617.

5. Sá, S., J.M. Sousa, and A. Mendes, Steam reforming of methanol over a CuO/ZnO/Al2O3 catalyst, part I: Kinetic modelling. Chemical Engineering Science, 2011. 66(20): p. 4913-4921.

6. Palo, D.R., R.A. Dagle, and J.D. Holladay, Methanol Steam Reforming for Hydrogen Production. Chemical Reviews, 2007. 107(10): p. 3992-4021.

7. Engineers, S.o.A., Hydrogen Specification Guideline for Fuel Cell Vehicles, 2005.

8. Andreasen, S.J., S.K. Kær, and S. Sahlin, Control and experimental characterization of a methanol reformer for a $350 \mathrm{~W}$ high temperature polymer electrolyte membrane fuel cell system. International Journal of Hydrogen Energy, 2013. 38(3): p. 1676-1684.

9. Jensen, J.O., et al., High temperature PEMFC and the possible utilization of the excess heat for fuel processing. International Journal of Hydrogen Energy, 2007. 32(10-11): p. 1567-1571.

10. Jiang, C.J., et al., Kinetic study of steam reforming of methanol over copper-based catalysts. Applied Catalysis A: General, 1993. 93(2): p. 245-255.

11. Lee, J.K., J.B. Ko, and D.H. Kim, Methanol steam reforming over Cu/ZnO/Al2O3 catalyst: kinetics and effectiveness factor. Applied Catalysis A: General, 2004. 278(1): p. 25-35.

12. Peppley, B.A., et al., Methanol-steam reforming on $\mathrm{Cu} / \mathrm{ZnO} / \mathrm{Al} 2 \mathrm{O} 3$ catalysts. Part 2. A comprehensive kinetic model. Applied Catalysis A: General, 1999. 179(1-2): p. 31-49.

13. Mastalir, A., et al., Steam reforming of methanol over $\mathrm{Cu} / \mathrm{ZrO} 2 / \mathrm{CeO} 2$ catalysts: a kinetic study. Journal of Catalysis, 2005. 230(2): p. 464-475.

14. Samms, S.R. and R.F. Savinell, Kinetics of methanol-steam reformation in an internal reforming fuel cell. Journal of Power Sources, 2002. 112(1): p. 13-29.

15. Tesser, R., M. Di Serio, and E. Santacesaria, Methanol steam reforming: A comparison of different kinetics in the simulation of a packed bed reactor. Chemical Engineering Journal, 2009. 154(1-3): p. 69-75.

16. Froment, G.F. and K.B. Bischoff, Chemical Reactor Analysis and Design. Second ed. 1990, New York: Wiley.

17. Shishido, T., et al., Active $\mathrm{Cu} / \mathrm{ZnO}$ and $\mathrm{Cu} / \mathrm{ZnO} / \mathrm{Al} 2 \mathrm{O} 3$ catalysts prepared by homogeneous precipitation method in steam reforming of methanol. Applied Catalysis A: General, 2004. 263(2): p. 249-253.

18. Jung, K. and A. Bell, Effects of Zirconia Phase on the Synthesis of Methanol over Zirconia-Supported Copper. Catalysis Letters, 2002. 80(1-2): p. 63-68.

19. Fernández-García, M., et al., Tracking Down the Reduction Behavior of Copper-onAlumina Catalysts. Journal of Catalysis, 1998. 178(1): p. 253-263.

20. Breen, J.P. and J.R.H. Ross, Methanol reforming for fuel-cell applications: development of zirconia-containing Cu-Zn-Al catalysts. Catalysis Today, 1999. 51(3-4): p. 521-533. 
03-11-2017

21. Turco, M., et al., $\mathrm{Cu} / \mathrm{ZnO} / \mathrm{Al} 2 \mathrm{O} 3$ catalysts for oxidative steam reforming of methanol: The role of $\mathrm{Cu}$ and the dispersing oxide matrix. Applied Catalysis B: Environmental, 2007. 77(1-2): p. 46-57.

22. Zhao, Y., K. Tao, and H.L. Wan, Effect of zirconia phase on the reduction behaviour of highly dispersed zirconia-supported copper oxide. Catalysis Communications, 2004. 5(5): p. 249-252.

23. Köppel, R.A., C. Stöcker, and A. Baiker, Copper- and Silver-Zirconia Aerogels: Preparation, Structural Properties and Catalytic Behavior in Methanol Synthesis from Carbon Dioxide. Journal of Catalysis, 1998. 179(2): p. 515-527.

24. Yong, S.T., et al., Review of methanol reforming-Cu-based catalysts, surface reaction mechanisms, and reaction schemes. International Journal of Hydrogen Energy, 2013. 38(22): p. 9541-9552.

25. Yu, K.M.K., et al., Non-syngas direct steam reforming of methanol to hydrogen and carbon dioxide at low temperature. Nat Commun, 2012. 3: p. 1230.

26. Idem, R.O. and N.N. Bakhshi, Kinetic modeling of the production of hydrogen from the methanol-steam reforming process over Mn-promoted coprecipitated Cu-Al catalyst. Chemical Engineering Science, 1996. 51(14): p. 3697-3708.

27. Purnama, H., et al., CO formation/selectivity for steam reforming of methanol with a commercial CuO/ZnO/Al2O3 catalyst. Applied Catalysis A: General, 2004. 259(1): p. 8394.

28. Santacesaria, E. and S. Carrá, Kinetics of catalytic steam reforming of methanol in a cstr reactor. Applied Catalysis, 1983. 5(3): p. 345-358.

29. Geissler, K., et al., Autothermal methanol reforming for hydrogen production in fuel cell applications. Physical Chemistry Chemical Physics, 2001. 3(3): p. 289-293. 